\title{
Relationship of Knowledge and Attitude to Visual Inspection of Acetic Acid (IVA) By Women of Childbearing Age
}

\author{
CrossMark \\ Mona Rahayu Putri ${ }^{1}$, Lia Fitria ${ }^{2}$, Indah Sri Wahyuni ${ }^{3}$, Saraswati Haylian Chiani ${ }^{4}$, Ernawati $^{5}$ \\ Manuscript submitted: 09 November 2020, Manuscript revised: 18 December 2020, Accepted for publication: 27 January 2021
}

\section{*Corresponding Author}

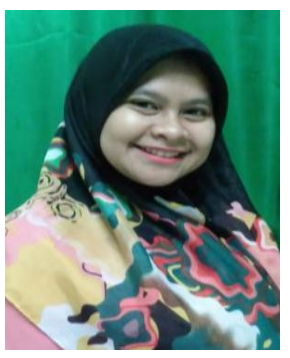

\section{Keywords}

attitude;

knowledge;

IVA Examination;

\begin{abstract}
Cervical cancer is the second most common cancer in Asia and more than half of Asian women die of cervical cancer. The purpose of this research is to find out the relationship of knowledge, attitude, and support of husband to IVA examination in Batu Aji health center in Batam. This research is analytical research with a cross-sectional approach by using Cluster Sampling. The sample size is 100 Women of Childbearing Age. Data collection tools with questionnaires. The analytical technique used the chi-square test. From the results of the study Women of Childbearing Age had low knowledge of IVA examination as many as 68 people (68\%), had a negative attitude as many as 63 people $(63 \%)$ and out of 100 respondents only 4 people (4\%) IVA checks. Based on the chi-square test with misunderstanding degree $\mathrm{p}<0.05$ it was found that there is a meaningful relationship between knowledge with IVA examination with $\mathrm{p}=0.009$ and $\mathrm{OR} 1,143$, also obtained a meaningful between attitude with IVA examination with $\mathrm{p}=1.01$ and OR 1,121. To solve this problem it is expected to health workers to provide information or counseling about IVA examinations to women of childbearing age.
\end{abstract}

International Journal of Health Sciences (C) 2021. This is an open access article under the CC BY-NC-ND license (https://creativecommons.org/licenses/by-nc-nd/4.0/).

\section{Contents}

Abstract

1 Introduction

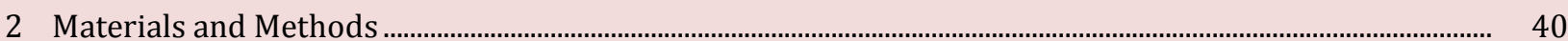

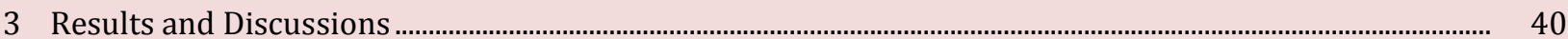

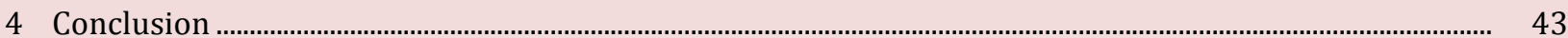

\footnotetext{
${ }^{1}$ Undergraduate Midwifery program, Institute Health Mitra Bunda, Batam, Indonesia

${ }^{2}$ Undergraduate Midwifery Program Faculty of Health Sciences Ibrahimy University, East Java, Indonesia

${ }^{3}$ Diploma III Midwifery Study Program of Karya Husada Polytechnic, Jakarta, Indonesia

${ }^{4}$ Department of Mathematics Education STKIP Paracendekia NW Sumbawa, Nusa Tenggara Barat, Indonesia

${ }^{5}$ Diploma III Midwifery Study Program of STIKes Karsa Husada Garut, West Java, Indonesia
} 


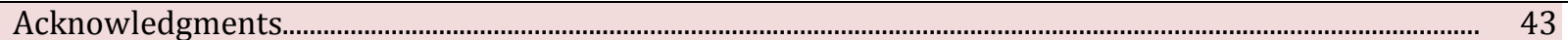

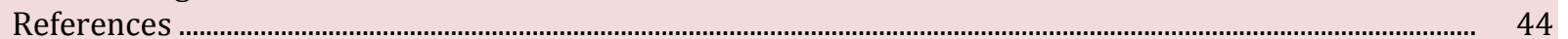

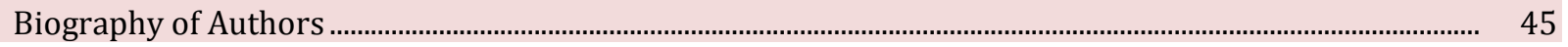

\section{Introduction}

Cervical cancer is a serious problem in women's reproductive health around the world. Serix cancer is the second leading cause of death among adult women. Globocan data (2012) International Agency for Research on Cancer (IARC) annually appears new cases of cervical cancer as many as 525,000 cases, and every year as many as 266,000 women die from cervical cancer. Based on Globocan data in 2013 cases of cervical cancer $(17.3$ per 100,000$)$ with a mortality rate of 8.2 per 100,000. (Falcone \& Hurd, 2007; Forouzanfar et al., 2011; (Franco et al., 2003). Cervical cancer is the second most common cancer in Asia and more than half of Asian women die of cervical cancer. Of the 226 thousand diagnosed with cervical cancer, 143 thou sand cause death or in other words every four minutes, women in Asia die of cervical cancer (Parkhurst \& Vulimiri, 2013; Ginsberg et al., 2012).

Indonesia has 15,000 new cases with 8,000 deaths each year, an estimated one woman dying every hour. The Ministry of Health of the Republic of Indonesia in 2015 stated that cervical cancer and breast cancer were the diseases with the highest prevalence in 2013, namely cervical cancer by $0.8 \%$. Riau Islands, North Maluku, and DI Yogyakarta provinces have the highest prevalence of cervical cancer. Cases of cervical cancer in The General Hospital of The Dewg Fatimah Area of Batam City from January 2013 to July 2014 were found there were 24 cases of 74,876 visits both outpatient and inpatient and most cases were advanced cervical cancer. (Rositch et al., 2014; Ibfelt et al., 2012).

The Visual Acetic Acid Method is chosen because it is cheap. This method can be implemented at the level of Public health center, auxiliary health centers, hospitals, maternity homes, and village midwives. Visual Acetic Acid method examination is an examination by directly observing the cervix that has been sucked with acetic acid or vinegar acid (3-5\%). Abnormal areas will change color with a firm border turning white (acetowhite), indicating that the cervix may have precancerous lesions. Women who have had sexual intercourse actively, especially those aged 30-50 years are recommended to do early detection/screening at least once every 5 years (Parkhurst \& Vulimiri, 2013).

Related to cervical cancer prevention programs, the ministry of health has targeted until 2025 that $80 \%$ of women aged 30-50 have done early detection of cervical cancer. However, from 2007-2013 early detection was carried out by as many as 644,951 people (1.75\%) with the number of Visual Inspection of Acetic Acid 3$5 \%$ positive amounted to 28,850 people $(4.47 \%)$. Based on the data, suspected uterine cancer laher as many as 840 people (1.3 per 1000 inhabitants). To achieve the target, the government expanded the implementation of early detection of cervical cancer to 140 districts in 31 provinces implemented by 500 health centers out of a total of 9500 health centers throughout Indonesia (Rositch et al., 2014).

According to WHO data, only 5\% of women in developing countries, including Indonesia, receive IVA services. While in developed countries, almost $70 \%$ of women conduct IVA examinations. As for one of the problems, the number of Indonesian women who do not conduct IVA examinations is because of shame, shame, and fear (Hendriksz et al., 2013). This is generally due to the low level of education and knowledge of Indonesians regarding IVA examination. (Batam City Government, 2016).

Batam City Health Office data in 2016 obtained from 98518 the number of targets only 906 were examined and obtained the results of visual inspection of positive acetic acid at the age of 30-50 years as many as 21 people and most of them in Batu Aji Health Center as many as 4 people. The number of sufferers increased compared to 2015, with 17 positive people out of 812 people examined. The number of women who conducted this examination is very far from the target number of the Regional Medium Term Development Plan (RPJMD) which is $0.9 \%$ of the expected $9 \%$ target. This is a big challenge, considering the target to be achieved by 2025 is that $80 \%$ of women should conduct a visual inspection of acetic acid. (Batam City Government, 2016).

Director of Non-Communicable Disease Control Ministry of Health said that many things can affect the low achievement of early detection of cervical cancer, ranging from low awareness and public knowledge about cervical cancer, women's fear of examination, the absence of a mass early detection program that is organized

Putri, M. R., Fitria, L., Wahyuni, I. S., Chiani, S. H., \& Ernawati, E. (2021). Relationship of knowledge and attitude to visual inspection of acetic acid (IVA) by women of childbearing age. International Journal of Health Sciences, 5(1), 38-45. https://doi.org/10.29332/ijhs.v5n1.750 
to the maximum, the difficulty of husbands to allow their wives to undergo examinations and sociocultural factors in society such as myths or beliefs in traditional medicine that have not been scientifically proven (Mulyani et al., 2017; Malterud, 2001; Church \& Goldin-Meadow, 1986). (Directorate General of NonCommunicable Disease Control, 2015). The initial survey conducted by researchers used the interview method of 10 (ten) sexually active fertile age women about visual inspection examination of acetic acid, saying that 7 of them did not know the purpose of visual inspection of acetic acid. Three people said they had heard of visual inspection of acetic acid on social media, but they were afraid and embarrassed to do the examination, they assumed that it was better not to know the disease than to know but always felt worried, so from the initial survey obtained $70 \%$ of women of childbearing age did not know about the visual inspection of acetic acid and all women of childbearing age had never done a visual inspection of acetic acid.

\section{Materials and Methods}

This type of research is analytical survey research with a cross-sectional approach. In this cross-sectional variable cause or risk and the consequences of cases that occur in research, objects are measured and collected simultaneously or at the same time. This research was carried out in the Working Area of Batu Aji Health Center. Data collection was done by using the filling out of questionnaires from house to house, starting from researchers introducing themselves to respondents, explaining the intentions and objectives of researchers, providing explanations on how to fill out questionnaires, then giving questionnaires to respondents to fill out. Analysis of the data used is Univariate Analysis using formulas

Description:

$$
X=\sum \frac{X i}{n}
$$

$\mathrm{X}=$ average value

$\mathrm{Xi}=$ Total respondents' overall score

$\mathrm{N}=$ number of samples

\section{Bivariate Analysis}

This analysis is done to test the relationship of free variables and bound variables. To see the difference in meaningful distribution between the two variables, it is done by statistical test chi-square. The chi-square test was conducted because the variables in this study were a category for category foregoric variables. Square statistical test analysis has a confidence level of $95 \%$.

\section{Results and Discussions}

Based on the results of data collection that have been done by researchers on the relationship of knowledge and attitude of WUS with IVA examination obtained data as follows:

a. Univariate Analysis

Table 1

Distribution of Frequency of Knowledge Level of Women of Childbearing Age to IVA Examination in The Working Area of Public health center Batu Aji Year 2018

\begin{tabular}{llll}
\hline No & Knowledge & Frequency & $\%$ \\
\hline 1 & High & 32 & 32 \\
2 & Low & 68 & 68 \\
& Amount & 100 & 100 \\
\hline
\end{tabular}


Based on table 1 above, it is known that some respondents have less knowledge about IVA examination as many as 68 people $(68 \%)$.

Table 2

Distribution of Frequency of Women of Childbearing Age attitude to IVA Examination in The Working Area of Public health center Batu Aji Year 2018

\begin{tabular}{lll}
\hline Attitude & Frequency & Percentage \\
\hline Positive & 37 & 37 \\
Negative & 63 & 63 \\
Total & 100 & 100 \\
\hline
\end{tabular}

From the table above, it can be seen that most respondents have a negative attitude towards the IVA examination of 63 people ( $63 \%)$.

Table 3

Distribution of Frequency of IVA Examination in The Working Area of Public health center Batu Aji the year 2018

\begin{tabular}{llll}
\hline No & IVA check & Frequency & Percentage \\
\hline 1. & Do & 4 & 4 \\
2. & Do not do & 96 & 96 \\
& Total & 100 & 100 \\
\hline
\end{tabular}

From the table above, it can be seen that most wus do not do IVA examination, which is 96 out of 100 women have not done IVA examination.

b. Bivariate Analysis

Table 4

Wus Knowledge Relationship with IVA Examination in Batu Aji Health Center working area year 2018

\begin{tabular}{|c|c|c|c|c|c|c|c|c|}
\hline \multirow{3}{*}{ Knowledge } & \multicolumn{5}{|c|}{ IVA Examination Behavior } & \multirow{3}{*}{$\begin{array}{r}\text { Total } \\
\quad \%\end{array}$} & \multirow{3}{*}{ P-Value } & \multirow{3}{*}{ OR } \\
\hline & \multicolumn{2}{|c|}{ Do } & \multicolumn{3}{|c|}{ Do Not Do } & & & \\
\hline & $\mathrm{F}$ & $\%$ & $\mathrm{~F}$ & $\%$ & $\mathrm{f}$ & & & \\
\hline High & 4 & 12,9 & 28 & 87,09 & 33 & 100 & 0,009 & 1,143 \\
\hline Low & 0 & 0 & 68 & 100 & 68 & 100 & $(1,003-1.303)$ & \\
\hline Total & 4 & 4 & 96 & 96 & 100 & 100 & & \\
\hline
\end{tabular}

Based on table 5, out of 32 respondents who have high knowledge only 4 respondents conduct IVA examinations while respondents who have low knowledge do not conduct examinations. After the statistical test using a computerized system to the relationship of knowledge with IVA examination obtained the result $p$ $=0.009(\mathrm{p}<0.05)$. This means there is a meaningful relationship between knowledge and IVA examination in the working area of Public health center Batu Aji in 2018. From the results of the study also obtained or the 1,143 value means that low knowledgeable respondents have a chance of 1,143 not conducting IVA examinations compared to highly knowledgeable respondents.

Putri, M. R., Fitria, L., Wahyuni, I. S., Chiani, S. H., \& Ernawati, E. (2021). Relationship of knowledge and attitude to visual inspection of acetic acid (IVA) by women of childbearing age. International Journal of Health Sciences, 5(1), 38-45. https://doi.org/10.29332/ijhs.v5n1.750 
Table 5

Relationship of WUS Attitude with IVA Examination in the Working Area of Batu Aji Health Center Year 2018

\begin{tabular}{|c|c|c|c|c|c|c|c|c|}
\hline \multirow{3}{*}{ Attitude } & \multicolumn{4}{|c|}{ IVA Examination Behavior } & \multirow{2}{*}{\multicolumn{2}{|c|}{ Total }} & \multirow{3}{*}{ P-value } & \multirow{3}{*}{ OR } \\
\hline & \multicolumn{2}{|c|}{ Do } & \multicolumn{2}{|c|}{ Do Not Do } & & & & \\
\hline & $\mathrm{F}$ & $\%$ & $\mathrm{~F}$ & $\%$ & $\mathrm{f}$ & $\%$ & & \\
\hline Positive & 4 & 10,8 & 33 & 89,18 & 37 & 100 & 0,017 & 1,121 \\
\hline Negative & 0 & 0 & 63 & 100 & 63 & 100 & $(1,002-1,254)$ & \\
\hline Total & 4 & 4 & 96 & 96 & 100 & 100 & & \\
\hline
\end{tabular}

Based on table 6, out of 37 respondents who had a positive attitude only 4 respondents conducted IVA examinations while respondents that had a negative attitude no one did the examination. After a statistical test using a computerized system against the relationship with the IVA examination, the result $\mathrm{p} 0.017=(\mathrm{p}<$ 0.05). This means that there is a meaningful relationship between knowledge and IVA examination poems in the working area of Public health center Batu Aji in 2018. The results of the study also obtained a value of OR 1,121 means that respondents who have a negative attitude are likely 1,121 to not conduct an IVA examination compared to respondents who have a positive attitude (Zhang et al., 2020).

\section{Relationship of Knowledge with WUS Behavior to IVA Examination}

The result of knowledge relationship analysis with WUS behavior to IVA examination obtained $\mathrm{p}$-value = $0.009(\mathrm{p}<0.05))$ so that it can be stated that there is a relationship between knowledge and WUS behavior to IVA examination. From the results of or analysis obtained or value of 1,143 which means respondents with a good level of knowledge have a 2 times chance to conduct IVA examinations compared to respondents who have less knowledge. This is in line with Notoatmodjo (2012), a statement which states that knowledge can be gained from experience derived from various sources of information to form a belief for a person. So that to increase public knowledge about IVA examinations, it is necessary to socialize about IVA that can be received through television, radio, magazines, cadres of health workers in the community.

The results of this study are following sakanti research, Salmah et al. (2013), that well-known person, as many as $85.71 \%$ conduct IVA examinations. In line with the results of Rasyid \& Afni (2017), that there is a significant relationship between knowledge and IVA check behavior in the Prembun Puskesmas Area with a value of $p=0,000.33$. (Wardhani et al., 2017).

Knowledge of early detection of cervical cancer is important to be known by the public, especially women to raise awareness and stimulate the formation of health behaviors that are expected in this case the behavior of early detection of cervical cancer. If a person's level of knowledge is lacking then the less a person interprets or applies what he knows, and on the contrary the better the level of knowledge a person is then the better in applying what he knows. This affects the behavior of respondents in conducting IVA tests (Sirait \& Nuranna, 2007).

According to researchers, the lack of knowledge obtained by WUS is due to the lack of information obtained from health workers and also because of the lack of motivation from the community itself to find out everything related to IVA examinations. In general, women do not pay attention to the health of reproductive devices, many women only underestimate their own reproductive devices, besides that the existing culture is also very affecting women's knowledge.

\section{Attitude Relationship with WUS Behavior to IVA Examination}

The result of the analysis of attitude relationship with WUS behavior to IVA examination obtained a p-value of $0.017=(p<0.05)$ so that it can be stated that there is a relationship between attitude and WUS behavior to IVA examination. From the results of or analysis obtained or value of 1,121 which means respondents with a positive attitude have a 2 times chance to conduct an IVA examination compared to respondents who have a negative attitude. 
An attitude is a form of evaluation or feeling of a person towards an object, namely a feeling of support or impartiality or a feeling of disfavor or impartiality of the object. This lack of knowledge about IVA screening caused pus women not to give a positive response to IVA examination (Levitsky, 1979). Research conducted by Mas'adah, Susilorin obtained more than 50\% of respondents have a positive attitude (Good) that is 21 $(55.26 \%)$ who perform IVA coercion. This is because most wus are well knowledgeable anyway about IVA. Research conducted by Mas'adah, Susilorin, the number of respondents who have negative sakap caused by the lack of knowledge of PUS women about IVA.40 examination (Wulandari et al., 2018).

\section{Conclusion}

There is a statistically significant relationship between WUS knowledge and IVA examination (OR=1,143: CI $95 \% \mathrm{p}=0.009(\mathrm{p}<0.05)$. There is a significant static relationship between WUS attitude and IVA examination $(\mathrm{OR}=1,143:$ CI $95 \% \mathrm{p}=0 \mathrm{p}=0.009(\mathrm{p}<0.05)$.

\section{Acknowledgments}

Thanks are conveyed to all those who played a role in making this research. Thank you to the Head of Puskesmas and IVA Program Holder at Puskesmas Baju Aji who has provided information so that this research can be well-researched and Thank you to all respondents who have taken the time to answer the research questionnaire so that the results in this study are obtained.

Putri, M. R., Fitria, L., Wahyuni, I. S., Chiani, S. H., \& Ernawati, E. (2021). Relationship of knowledge and attitude to visual inspection of acetic acid (IVA) by women of childbearing age. International Journal of Health Sciences, 5(1), 38-45. https://doi.org/10.29332/ijhs.v5n1.750 


\section{References}

Church, R. B., \& Goldin-Meadow, S. (1986). The mismatch between gesture and speech as an index of transitional knowledge. Cognition, 23(1), 43-71. https://doi.org/10.1016/0010-0277(86)90053-3

Falcone, T., \& Hurd, W. W. (Eds.). (2007). Clinical reproductive medicine and surgery.

Forouzanfar, M. H., Foreman, K. J., Delossantos, A. M., Lozano, R., Lopez, A. D., Murray, C. J., \& Naghavi, M. (2011). Breast and cervical cancer in 187 countries between 1980 and 2010: a systematic analysis. The lancet, 378(9801), 1461-1484. https://doi.org/10.1016/S0140-6736(11)61351-2

Franco, E. L., Schlecht, N. F., \& Saslow, D. (2003). The epidemiology of cervical cancer. The Cancer Journal, 9(5), 348-359.

Ginsberg, G. M., Lauer, J. A., Zelle, S., Baeten, S., \& Baltussen, R. (2012). Cost effectiveness of strategies to combat breast, cervical, and colorectal cancer in sub-Saharan Africa and South East Asia: mathematical modelling study. Bmj, 344.

Hendriksz, C. J., Harmatz, P., Beck, M., Jones, S., Wood, T., Lachman, R., ... \& Tomatsu, S. (2013). Review of clinical presentation and diagnosis of mucopolysaccharidosis IVA. Molecular genetics and metabolism, 110(1-2), 54-64. https://doi.org/10.1016/j.ymgme.2013.04.002

Ibfelt, E., Kjær, S. K., Johansen, C., Høgdall, C., Steding-Jessen, M., Frederiksen, K., ... \& Dalton, S. O. (2012). Socioeconomic position and stage of cervical cancer in Danish women diagnosed 2005 to 2009. Cancer Epidemiology and Prevention Biomarkers, 21(5), 835-842.

Levitsky, D. A. (1979). Malnutrition, environment, and behavior: New perspectives. Cornell U. Press.

Malterud, K. (2001). The art and science of clinical knowledge: evidence beyond measures and numbers. The Lancet, 358(9279), 397-400. https://doi.org/10.1016/S0140-6736(01)05548-9

Mulyani, S., Subiyanto, A. A., Anantanyu, S., Respati, S. H., \& Wiboworini, B. (2017). Path analysis: knowledge, motivation factor, and their relationship with readiness to provide exclusive breastfeeding among pregnant women. International Research Journal of Management, IT and Social Sciences, 4(1), 8-14.

Notoatmodjo, S. (2012). Promosi kesehatan dan perilaku kesehatan. Jakarta: rineka cipta, 45-62.

Parkhurst, J. O., \& Vulimiri, M. (2013). Cervical cancer and the global health agenda: insights from multiple policy-analysis frameworks. Global public health, 8(10), 1093-1108.

Rasyid, N., \& Afni, N. (2017). Faktor-Faktor Yang Berhubungan Dengan Perilaku WUS (Wanita Usia Subur) Tentang Deteksi Dini Kanker Leher Rahim Metode IVA (Inspeksi Visual Asam Asetat). PROMOTIF: Jurnal Kesehatan Masyarakat, 7(1), 63-75.

Rositch, A. F., Nowak, R. G., \& Gravitt, P. E. (2014). Increased age and race-specific incidence of cervical cancer after correction for hysterectomy prevalence in the United States from 2000 to 2009. Cancer, 120(13), 2032-2038.

Salmah, S., Rajab, W., \& Djulaeha, E. (2013). Faktor Dominan yang Berhubungan dengan Perilaku Pemeriksaan Pap Smear Pada Wanita Usia Subur. Jurnal Ilmu Dan Teknologi Kesehatan, 1(1), 5-11.

Sirait, A. M., \& Nuranna, L. (2007). Deteksi Dini Kanker Serviks dengan Metode Inspeksi Visual Asam Asetat di Depok. Indonesian Journal of Obstetrics and Gynecology.

Wardhani, G. K., Mudigdo, A., \& Qadrijati, I. (2017). Path analysis on the determinants of Pap smear utilization for cervical cancer early detection in women of reproductive age. Journal of Health Promotion and Behavior, 2(4), 359-370.

Wulandari, A., Wahyuningsih, S., \& Yunita, F. (2018). Faktor-faktor yang Berhubungan dengan Perilaku Pemeriksaan Inspeksi Visual Asam Asetat (IVA) pada Wanita Usia Subur (WUS) di Puskesmas Sukmajaya Tahun 2016. Jurnal Kedokteran Universitas Lampung, 2(2), 93-101.

Zhang, M., Zhou, M., Tang, F., Wang, Y., Nie, H., Zhang, L., \& You, G. (2020). Knowledge, attitude, and practice regarding COVID-19 among healthcare workers in Henan, China. Journal of Hospital Infection, 105(2), 183187. https://doi.org/10.1016/j.jhin.2020.04.012 


\section{Biography of Authors}

\begin{tabular}{|c|c|}
\hline & $\begin{array}{l}\text { Mona Rahayu Putri, S.ST, MKM } \\
\text { She is a lecturer in the Undergraduate Program Midwifery and Midwifery } \\
\text { Professional Education at the Mitra Bunda Health Institute (2012 to } \\
\text { present) Educational Background: Diploma IV Midwifery at Fort De Kock } \\
\text { Bukittinggi University (2012), Master of Public Health at the Helvetia } \\
\text { Health Institute Medan (2015) } \\
\text { Email: putrimonarahayu@gmail.com }\end{array}$ \\
\hline & $\begin{array}{l}\text { Lia Fitria, S.ST., M. Keb } \\
\text { She is a Lecturer in the Diploma -III Midwifery Study Program, Faculty of Health, } \\
\text { Ibrahimy Situbondo University, East Java (2009 to present). Educational } \\
\text { Background: D4 Midwifery at STIKES INSAN UNGGUL SURABAYA (2010), Master } \\
\text { of Midwifery at Padjadjaran University, Bandung (2017). } \\
\text { Email : leeafitria@gmail.com }\end{array}$ \\
\hline & $\begin{array}{l}\text { Indah Sri Wahyuni, SST, SKM, MKM } \\
\text { She is a lecturer in the Midwifery Diploma III Study Program of the Karya Husada } \\
\text { Polytechnic, Jakarta (2006 to present). Educational Background: Diploma III } \\
\text { Midwifery Health Polytechnic Malang (2000-2003), Undergraduate Public Health } \\
\text { Sciences Program, Faculty of Public Health, University of Indonesia (2004-2006), } \\
\text { Diploma IV Midwifery Polytechnic Karya Husada (2009-2010), Master of Public } \\
\text { Health Sciences, Faculty of Public Health, University of Indonesia (2011-2013) } \\
\text { Email : indahsekali03@gmail.com }\end{array}$ \\
\hline $\begin{array}{l}\overline{\mathrm{DIP}} \\
\mathrm{DE}\end{array}$ & $\begin{array}{l}\text { Saraswati Haylian Chiani, SST., M.Kes. } \\
\text { Educational background pursued by DIII Midwifery at Respati Yogyakarta } \\
\text { University in 2011, DIV Educator Midwife at Respati Yogyakarta University } \\
\text { in } 2012 \text { and Masters in Family Medicine Specializing in Health Professional } \\
\text { Education at Sebelas Maret University Surakarta in 2014. Joined the IBI } \\
\text { Bima Regency Organization since } 2017 \text { and the TEAM IVA Bima Regency } \\
\text { through the Bima Regent Decree } 2017 . \\
\text { Email: saraswatichiani@gmail.com }\end{array}$ \\
\hline & $\begin{array}{l}\text { Ernawati, S.ST., M.Kes, } \\
\text { She is a Lecturer at STIKes Midwifery Study Program, Karsa Husada Garut, West } \\
\text { Java, Indonesia ( } 2012 \text { to present), Educational background: D3 Midwifery STIKes } \\
\text { Karsa Husada Garut (2011), D4 Midwifery STIKIM Jakarta (2014), Master of Public } \\
\text { Health STIKIM Jakarta (2018) } \\
\text { Email: ernawatikoesendang@gmail.com }\end{array}$ \\
\hline
\end{tabular}

Putri, M. R., Fitria, L., Wahyuni, I. S., Chiani, S. H., \& Ernawati, E. (2021). Relationship of knowledge and attitude to visual inspection of acetic acid (IVA) by women of childbearing age. International Journal of Health Sciences, 5(1), 38-45. https://doi.org/10.29332/ijhs.v5n1.750 